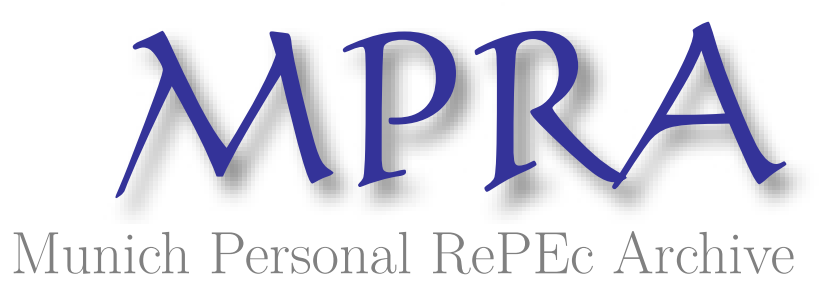

\title{
Financial stability, new macro prudential arrangements and shadow banking: regulatory arbitrage and stringent Basel III regulations
}

\author{
Ojo, Marianne
}

Lessing Trebing Bert Rechtsanwälte, Oxford Brookes University

10 June 2011

Online at https://mpra.ub.uni-muenchen.de/31319/

MPRA Paper No. 31319, posted 07 Jun 2011 20:27 UTC 


\begin{abstract}
Despite Basel III's efforts to address capital and liquidity requirements, will the risks linked to regulatory arbitrage increase as a result of Basel III's more stringent capital and liquidity rules?

As well as Basel III reforms which are geared towards greater facilitation of financial stability on a macro prudential basis, further efforts and initiatives aimed at mitigating systemic risks - hence fostering financial stability, have been promulgated through the establishment of the De Larosiere Group, the European Systemic Risk Board, and a working group comprising of "international standard setters and authorities responsible for the translation of G20 commitments into standards."
\end{abstract}

This paper aims to investigate the impact of Basel III on shadow banking and its facilitation of regulatory arbitrage as well as consider the response of various jurisdictions and standard setting bodies to aims and initiatives aimed at improving their macro prudential frameworks. Furthermore, it will also aim to illustrate why immense work is still required at European level - as regards efforts to address systemic risks on a macro prudential basis. This being the case even though significant efforts and steps have been taken to address the macro prudential framework. In so doing, the paper will also attempt to address how coordination within the macro prudential framework - as well as between micro and macro prudential supervision could be enhanced.

Key Words: counter party risks, liquidity, European Systemic Risk Board, stability, systemic risk, shadow banking, central banks, regulatory arbitrage, OTC derivatives, European Central Bank, supervision, coordination 


\section{Abbreviations}

$\begin{array}{ll}\text { ABS } & \text { Asset Backed Securities } \\ \text { ABCP } & \text { Asset Backed Commercial Paper } \\ \text { CCPs } & \text { Central Counterparties } \\ \text { CCR } & \text { Counterparty Credit Risk } \\ \text { CDO } & \text { Collateralized Debt Obligations } \\ \text { CEBS } & \text { Committee of European Banking Supervisors } \\ \text { CEIOPS } & \text { Committee of European Insurance and Occupational Pensions Committee } \\ \text { CESR } & \text { Committee of European Securities Regulators } \\ \text { ESA } & \text { European Supervisory Authority } \\ \text { ESFS } & \text { European System of Financial Supervisors } \\ \text { ESRC } & \text { European Systemic Risk Board } \\ \text { ECB } & \text { European Central Bank } \\ \text { FPC } & \text { Financial Policy Committee } \\ \text { FSOC } & \text { Financial Stability Oversight Council } \\ \text { NCB } & \text { National Central Bank } \\ \text { OTC } & \text { Over-the-Counter }\end{array}$




\title{
Financial Stability, New Macro Prudential Arrangements and Shadow Banking: Regulatory Arbitrage and Stringent Basel III Regulations
}

\author{
Marianne Ojo ${ }^{1}$
}

\section{A. Introduction}

\section{Recent Efforts Aimed at Fostering Financial Stability}

The establishment of the De Larosiere Group was announced by the Commission in a move aimed at "considering the organization of European financial institutions to ensure prudential soundness, the orderly functioning of markets and stronger European cooperation on financial stability oversight, early warning mechanisms and crisis management (including the management of cross border and cross sectoral risks), as well as looking at cooperation between the European Union and other major jurisdictions to help safeguard financial stability at the global level."2 Other more recent moves aimed at fostering macro financial stability as well as "contributing directly to achieving the objectives of the Internal Market", include the establishment of the European Systemic Risk Board (ESRB) and a working group 3 comprised of international standard setters and authorities responsible for the translation of G20 commitments into standards. Purpose of the establishment of the Working Group being to make recommendations on the implementation of objectives ${ }^{4}$ aimed at "improving transparency in the derivatives markets, mitigating systemic risk, and protecting against market abuse." The establishment of the De Larosiere Group, the ESRB and the Working Group not only highlights the importance attached to aims directed at fostering and promoting financial stability, but also the paramount importance attached to the need to manage systemic risks - as well as the need to regulate the OTC (Over - the- Counter) derivatives markets.

1 Lessing Trebing Bert Rechtsanwälte, Frankfurt and Oxford Brookes University, Oxford. Email: marianneojo@hotmail.com

2

See Commission Communication, "From Financial Crisis to Recovery: A European Framework for Action” COM (2008) 706 final 29 October 2008 <http://eur-lex.europa.eu/LexUriServ/LexUriServ.do? uri=COM:2008:0706:FIN:EN:PDF>

Working group was led by representatives of the Committee on Payment and Settlement Systems (CPSS), the International Organization of Securities Commissions (IOSCO) and the European Commission. The Working Group's focus was also directed at "common approaches to OTC derivatives markets to achieve consistency in implementation across jurisdictions whilst promoting greater use of OTC derivatives products in standardised form and the minimization of possibilities for regulatory arbitrage." See Financial Stability Board, "Implementing OTC Derivatives Market Reforms" Oct 2010

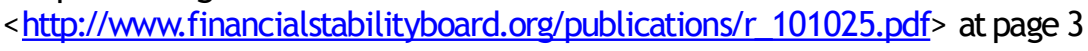


Hence the paper will commence with a section dedicated to the contribution of the OTC derivatives markets to financial instability - as well as measures which have been proposed and implemented in the attempt and challenge to manage different types of risks which exist within the banking and investment sectors - particularly, counterparty and liquidity risks. Section C of the paper will then consider why there has been increased focus in the significance attached to the roles of central banks in crisis management, financial stability and the supervisory coordination process. Section D elaborates on the factors which have prompted the need for a reform of macro prudential supervision at European level. This will be followed by a section (section E) which highlights the need for improved coordination between micro and macro prudential aspects of financial supervision - as well as incorporates discussions on the ECB's macro prudential expertise, the involvement of micro prudential supervisors and a member of the Commission in the work of the ESRB. It will also consider recent efforts aimed at addressing systemic risks at macro prudential level by primarily focusing on the European Systemic Risk Board. Reason for such a focus being an insufficient emphasis on macro prudential oversight and inter linkages - with respect to the present arrangements of the European Union. To facilitate an analysis of the efforts which will and may still be required, reference will be made to other macro prudential frameworks. Furthermore, present efforts to incorporate the European Central Bank (ECB)'s expertise, as well as those of national central banks, European Supervisory Authorities, the European System of Financial Supervisors (ESFS) will be considered.

The significance of shadow banking - as well as the channels through which shadow banking activities are carried out, will then be introduced under Section F. This will be followed by a section dedicated to a consideration of efforts aimed at addressing regulatory arbitrage before a conclusion is derived.

\section{B. Financial Stability}

"In order to ensure financial stability, the Commission should review and report on measures to enhance the transparency of OTC markets, to mitigate the counterparty risks and more generally to reduce the overall risks, such as by clearing of credit default swaps through central counterparties (CCPs). The establishment and development of CCPs in the EU subject to high operational and prudential standards and effective supervision should be encouraged. The Commission should submit its report to the European Parliament and the Council together with any appropriate proposals, taking into account parallel initiatives at the global level as appropriate., ${ }^{, 5}$

\section{Principal Contributory Factors to Financial Instability}

Weaknesses in OTC derivatives markets that had contributed to the build-up of systemic risk, as revealed during the recent Crisis included: ${ }^{6}$ "the build-up of large counterparty exposures between

5

See DIRECTIVE 2009/111/EC OF THE EUROPEAN PARLIAMENT AND OF THE COUNCIL of 16 September 2009 amending Directives 2006/48/EC, 2006/49/EC and 2007/64/EC as regards banks affiliated to central institutions, certain own funds items, large exposures, supervisory arrangements, and crisis management at page 5 of 23 
particular market participants which were not appropriately risk-managed; and contagion risk arising from the web of interconnectedness of market participants created by bilateral clearing of OTC derivatives products; and the limited transparency of overall counterparty credit risk exposures."

\section{Counterparty Risks}

Counterparty risks constitute the most significant of risks which exist within the financial markets owing to their nature, magnitude, as well as the extent to which such risks are regulated.

As part of efforts aimed at mitigating counterparty credit risk - which constitutes a fundamental component of systemic risk in OTC derivative markets, it was agreed by G-20 leaders that all standardized derivatives should be cleared through central counterparties latest by the end of $2010{ }^{7}$ From this the importance of the central clearing channel as a means of mitigating systemic risks can be inferred. Non centrally cleared contracts are to be subjected to: i) higher capital requirements to reflect their risk levels; ii) more consolidated bilateral counterparty risk management requirements. ${ }^{8}$ Despite the stated advantages attributed to central and standardized clearing procedures, legal and operational standardization is considered to impose structures and limitations on the economic function of a derivatives product - hence the reason why market participants seeking to hedge a specific risk may not find a standardized product that would effectively suit their exposure and hence opt instead, to use a bespoke product. ${ }^{9}$

Credit counterparty risks (CCR) exist within credit institutions - as well as emanate from investment institutions. Institutions are required to hold capital against counterparty credit risks arising from exposures attributed to OTC derivative instruments and credit derivatives; repurchase agreements, reverse repurchase agreements, securities or commodities lending or borrowing transactions based on securities or commodities included in the trading book; margin lending transactions based on

Bespoke products may be particularly susceptible to these weaknesses, as evidenced by market participants' failure to appropriately risk manage a number of bespoke credit derivatives products. The G-20 commitments aim to mitigate the systemic risk of bespoke products in the future by increasing standardisation and transparency. See Financial Stability Board, “Implementing OTC Derivatives Market Reforms” Oct 2010 $<$ http://www.financialstabilityboard.org/publications/r 101025.pdf > at page 19. For further reasons attributed to the preference of bespoke products, see pages 19-21

7

See ibid at page 23

8

Ibid; Furthermore, as a means of increasing the incentives to implement central clearing procedures, mandatory clearing guidelines are to be stipulated for non centrally cleared contracts.

Even though bespoke OTC derivatives often do not have the level of standardization required for central clearing or trading on organized platforms - since they are customized to meet particular user needs. See ibid at page 19 
securities or commodities; and long settlement transactions. ${ }^{10}$ As well as credit risks, other significant types of risks which exist within credit institutions are as follows: ${ }^{11}$

Liquidity risks, market risks, legal risks, operational risks ${ }^{12}$, residual risks ${ }^{13}$, concentration risk, securitisation risk and interest rate risks arising from non trading activities.

Risks attributed to investment institutions include ${ }^{14}$ market risks, counterparty/settlement risks, foreign exchange risks, interest rate risks and operational risks.

Whilst it is argued that OTC derivatives benefit financial markets, as well as the wider economy by "improving the pricing of risk, adding to liquidity, helping market participants manage their respective risks" ${ }^{15}$, flaws inherent in the structure of such derivatives - "the potential for contagion arising from the interconnectedness of OTC derivatives market participants and the limited transparency of counterparty relationships, ${ }^{\text {"16 }}$ were also revealed during the recent Crisis.

10

DIRECTIVE 2006/49/EC OF THE EUROPEAN PARLIAMENT AND OF THE COUNCIL of 14 June 2006 on the capital adequacy of investment firms and credit institutions (recast) at page 32 of 55.

See Annex V, Technical Criteria Concerning the Organisation and Treatment of Risks DIRECTIVE 2006/48/EC OF THE EUROPEAN PARLIAMENT AND OF THE COUNCIL of 14 June 2006 relating to the taking up and pursuit of the business of credit institutions (recast) at pages 79-80 of 200.

12

"Operational risks are significant risks faced by institutions and require coverage by own funds. It is of vital essence to take into account the diversity of institutions in the EU - through the provision of alternative approaches." See paragraph 25, DIRECTIVE 2006/49/EC OF THE EUROPEAN PARLIAMENT AND OF THE COUNCIL of 14 June 2006 on the capital adequacy of investment firms and credit institutions (recast)

page 2

13

"The risk that recognized credit risk mitigation techniques used by a credit institution will prove less effective than expected."

14

See DIRECTIVE 2006/49/EC OF THE EUROPEAN PARLIAMENT AND OF THE COUNCIL of 14 June 2006 on the capital adequacy of investment firms and credit institutions (recast) at page 2

15

Financial Stability Board, “Implementing OTC Derivatives Market Reforms" Oct 2010 $<$ http://www.financialstabilityboard.org/publications/r 101025.pdf>at page 1 
Two principal contributory factors to financial instability (at macro level) which are in need of urgent redress are liquidity risks and counter party credit risks. Even though risks have been classified under Directives 2006/48/EC and 2006/49/EC according to whether they are attributed to credit or investment institutions, paragraph 11 of the DIRECTIVE 2006/49/EC OF THE EUROPEAN PARLIAMENT AND OF THE COUNCIL of 14 June 2006 highlights the fact that investment firms face the same risks as credit institutions in their trading book business. ${ }^{17}$

Whilst it is difficult to assign an order of priority between liquidity and counterparty credit risks, liquidity risks could be considered to have a marginally higher ranked order of priority than counterparty credit risks.

According to paragraph 30 of the Preamble to the DIRECTIVE 2009/111/EC OF THE EUROPEAN PARLIAMENT AND OF THE COUNCIL of 16 September 2009, ${ }^{18}$ "recent market developments have highlighted the fact that liquidity risk management is a key determinant of the soundness of credit institutions and their branches."

\section{Harmonisation as a Vital Tool in the Facilitation of Effective Coordination and Supervision}

A harmonized set of standards or rules is essential to the facilitation of effective coordination and supervision. "Liquidity supervision at the level of a branch in another Member State," according to the Commission Services, will not be necessary anymore - owing to a harmonized liquidity standard and the progress that has been achieved by the Reorganization and Winding up Directive of 2001.

In relation to supervisory arrangements which are aimed at achieving a harmonized set of rules, and with particular respect to liquidity standards, recital 7 of Directive 2006/48/EC states that "it is appropriate to effect only the essential harmonization necessary and sufficient to secure the mutual recognition of authorization and of prudential supervision systems."

In respect of credit institutions with significant branches in another Member State, liquidity supervision could be considered to be the responsibility of the home Member State in close collaboration with the host Member States "if a harmonized set of liquidity rules is in place". ${ }^{19}$

ibid

17

(L 177/202 Official Journal of the European Union, on the capital adequacy of investment firms and credit institutions (recast)

Paragraph 11 states that "Since investment firms face in respect of their trading book business the same risks as credit institutions, it is appropriate for the pertinent provisions of Directive 2006/ 48/EC of the European Parliament and of the Council of 14 June 2006 relating to the taking up and pursuit of the business of credit institutions (1) to apply equally to investment firms."

amending Directives 2006/48/EC, 2006/49/EC and 2007/64/EC as regards banks affiliated to central institutions, certain own funds items, large exposures, supervisory arrangements, and crisis management. See page 4 of 23. 
Paragraph 25 of the Commission Services Staff Working Document ${ }^{20}$ makes reference to Article 41, first sub paragraph of Directive 2006/48/EC which provides that host Member States "retain responsibility for the supervision of liquidity of branches of EU credit institutions, but only pending further coordination." Furthermore, "if continued coordination is achieved by setting uniform liquidity standards in the EU, this subparagraph could be deleted, and supervisory arrangements for liquidity would no longer be different from those for solvency supervision." This, according to paragraph 25, would suffice for the liquidity standard to achieve the standard of "essential harmonization" referred to under recital 7 of Directive 2006/48/EC.

A harmonized liquidity standard is certainly very helpful in contributing to consistency and coordination - however it should be used as a general benchmark - which can be deviated from (to a minimal extent) in justified exceptional cases and depending on individual circumstances of the Member States involved. Where such Member States' liquidity standards significantly differ from such a benchmark, then these Member States' liquidity standards should not be applied.

Several stages were identified by the Commission in its Communication ${ }^{21}$ as phases through which the route from financial instability to financial stability are to be achieved. These are as follows:

i) Stabilisation of the Crisis

ii) Restructuring the banking sector

iii) Hand-over of banks to the private sector at some stage in the future

Furthermore, continued strong support for the financial system from the European Central Bank and other central banks; a rapid and consistent implementation of the bank rescue plans established by Member States; as well as decisive measures required to mitigate the spread of the Crisis across Member States ${ }^{22}$ were also highlighted as vital routes which had to be taken if the path to recovery was to be successful. The following section considers the role of central banks and the European Central Bank in the above mentioned phases, as well as in the process of ensuring that effective coordination of supervisory arrangements is achieved.

See paragraph 28, Commission Services Staff Working Document, "Possible Further Changes to the Capital Requirements Directive : Supervisory Responsibility for Branch Liquidity" at page 13 of 99

20

On "Possible Further Changes to the Capital Requirements Directive"; ibid at page 12 of 99

See European Commission, Communication from the Commission_From Financial Crisis to Recovery: A European Framework for Action at page 3 29.10.2008 COM (2008) 706 final < http://eurlex.europa.eu/LexUriServ/LexUriServ.do?uri=COM:2008:0706:FIN:EN:PDF> 


\section{The Increased Importance and Roles of Central Banks in Crisis Management, Financial Stability and the Supervisory Coordination Process.}

\section{Directive 2009/111/EC of the European Parliament and of the Council of 16 September 2009}

The importance of incorporating central banks into the supervisory process - given their vital roles as lenders of last resort facilities and crucial providers of liquidity support, as well as the importance of improved coordination in emergency situations is highlighted in the Directive 2009/111/EC of the European Parliament and of the Council of 16 September 2009.3.

Paragraph 6 of the Preamble states that "for the purpose of strengthening the crisis management framework of the Community, it is essential that competent authorities coordinate their actions with other competent authorities and, where appropriate, with central banks in an efficient way, including with the aim of mitigating systemic risk." With respect to consolidated supervision, the importance of establishing Colleges of Supervisors is also emphasized.

According to Article 129 paragraph 1 of Directive 2006/48/EC:

1. In addition to the obligations imposed by the provisions of this Directive, the competent authority responsible for the exercise of supervision on a consolidated basis of EU parent credit institutions and credit institutions controlled by EU parent financial holding companies shall carry out the following tasks:

(a) coordination of the gathering and dissemination of relevant or essential information in going concern and emergency situations; and

(b) planning and coordination of supervisory activities in going concern as well as in emergency situations, including in relation to the activities in Article 124, in cooperation with the competent authorities involved.

\section{Amendments by Directive 2009/111/EC of the European Parliament and of the Council of 16} September 2009

Article 129 (as amended by Directive 2009/111/EC of the European Parliament and of the Council of 16 September 2009) is amended as follows:

\section{Amendment 1}

\section{Paragraph 1 point (b)}

(formally:

(b) planning and coordination of supervisory activities in going concern as well as in emergency situations, including in relation to the activities in Article 124, in cooperation with the competent authorities involved.

is replaced by the following:

\section{3}

Amending Directives 2006/48/EC, 2006/49/EC and 2007/64/EC as regards banks affiliated to central institutions, certain own funds items, large exposures, supervisory arrangements, and crisis management. 
(b)planning and coordination of supervisory activities in going-concern situations, including in relation to the activities referred to in Articles 123, 124, 136, in Chapter 5 and in Annex V, in cooperation with the competent authorities involved;

c) planning and coordination of supervisory activities in cooperation with the competent authorities involved, and if necessary with central banks, in preparation for and during emergency situations, including adverse developments in credit institutions or in financial markets using, where possible, existing defined channels of communication for facilitating crisis management.

The planning and coordination of supervisory activities referred to in point (c) includes exceptional measures referred to in Article 132(3)(b), the preparation of joint assessments, the implementation of contingency plans and communication to the public.';

\section{Amendment 2}

\section{Furthermore, the following paragraph is added to Article 129 (as paragraph 3)}

Paragraph 3:

The consolidating supervisor and the competent authorities responsible for the supervision of subsidiaries of an EU parent credit institution or an EU parent financial holding company in a Member State shall do everything within their power to reach a joint decision on the application of Articles 123 and 124 to determine the adequacy of the consolidated level of own funds held by the group with respect to its financial situation and risk profile and the required level of own funds for the application of Article 136(2) to each entity within the banking group and on a consolidated basis.

The joint decision shall be reached within four months after submission by the consolidating supervisor of a report containing the risk assessment of the group in accordance with Articles 123 and 124 to the other relevant competent authorities. The joint decision shall also duly consider the risk assessment of subsidiaries performed by relevant competent authorities in accordance with Articles 123 and 124.

The Committee of European Banking Supervisors shall elaborate guidelines for the convergence of supervisory practices with regard to the joint decision process referred to in this paragraph and with regard to the application of Articles 123, 124 and 136(2) with a view to facilitating joint decisions.';

According to paragraph 9 of the Preamble to the Directive 2009/111/EC of the European Parliament and of the Council of 16 September 2009 (amending Directives 2006/48/EC, 2006/49/EC and 2007/64/EC as regards banks affiliated to central institutions, certain own funds items, large exposures, supervisory arrangements, and crisis management),

Article 129(3) of Directive 2006/48/EC "should not change the allocation of responsibilities between competent supervisory authorities on a consolidated, sub-consolidated and individual basis."

However, the subsequent paragraph, paragraph 10 acknowledges what role information deficits between the home and the host competent authorities could play - as well as the detrimental nature of such deficits to the financial stability in host Member States. As a result, paragraph 10 of the Preamble stipulates that "the information rights of host supervisors, in particular in a crisis involving significant branches, should be reinforced." Furthermore, it adds that the notion of significant branches should be defined and that competent authorities should transmit information which is essential for the pursuance of the tasks of central banks and Ministries of Finance with respect to financial crises and systemic risk mitigation.

With respect to the role of central banks in situations involving crisis management and resolution, the role to be assumed by the European Central Bank (with respect to the EU macro prudential oversight framework), will be of interest, given that "the ESRB does not have explicit tasks and powers on crisis management - apart from the power to advise the council on the existence of an emergency situation." 24 With respect to other macro prudential oversight arrangements, the Federal Reserve and the Bank of England, by virtue of their expertise and the positions they assume as central banks, are capable of responding in crisis situations - as liquidity providers and lenders of last resort. The ECB, 
with its capacity to engage central banks of Member States, as well as its expertise should definitely be involved (to a large extent) in crisis management situations. The new system of European supervision, as well as the ECB's expertise are amongst some of the topics which will be considered in the next section.

\section{The Need for a New System of Supervision at European Level}

Coordination or rather, the lack of coordination between different levels of supervision in the Union has been acknowledged has having contributed to the need for a new system for European Supervision. As well as facilitating early warning signals, a well coordinated system of supervision is crucial to ensuring that information is promptly transmitted across the relevant channels to its target. A fragmented system of supervision, the need for consistency in the application of rules across member states (harmonization) and the need for a mechanism in resolving agreements and taking action in emergency situations are all areas which were acknowledged to be in need of redress. Furthermore, lack of adequate mechanism for macro prudential supervision, lack of early warning mechanisms, as well as lack of resources for the level 3 Committees [the Committee of European Banking Supervisors (CEBS), the Committee of European Insurance and Occupational Pensions Committee (CEIOPS) and the Committee of European Securities Regulators (CESR)], were also contributory to the need for a new system of financial supervision.

Several serious flaws which provide justification for the need for a revised system of financial supervision in the EU - and particularly, the need for the new European Supervisory Authorities were identified in the report of the De Larosiere Group. The new authorities, the European Supervisory Authorities, are to consolidate on the Lamfalussy level 3 Committees [the Committee of European Banking Supervisors (CEBS), the Committee of European Insurance and Occupational Pensions Committee (CEIOPS) and the Committee of European Securities Regulators (CESR)]. The new supervisory authorities comprise the European Supervisory Authority (European Banking Authority) established by Regulation (EU) No 1093/2010; the European Supervisory Authority (European Insurance and Occupational Pensions Authority) established by Regulation (EU) No 1094/2010; the European Supervisory Authority (European Securities and Markets Authority) established by Regulation (EU) No 1095/2010.

"With respect to the EU framework, the ECB has a key role in providing analytical and statistical support to the ESRB. However, macro prudential oversight is not integrated with micro prudential supervision within the EU framework - given the fact that supervision will continue to be carried out principally by national supervisory authorities - with the European Supervisory Authorities having a mainly coordinating role." For further information on this, refer to the second table of the Annex to this paper and see also, European Central Bank, Financial Stability Review December 2010 at pages 60 and 61. 


\section{The Need for Improved Coordination between National Supervisors}

It is acknowledged that although a single market exists, as well as the operation of cross border financial institutions, several problems warranted the creation of the new European Supervisory Authorities: ${ }^{25}$

- The existence of an uneven and often uncoordinated system of supervision.

- $\quad$ The need for convergence between member states on technical rules

- The need for a mechanism for ensuring agreement and coordination between national supervisors of the same cross border institution or in colleges of supervisors.

- Rapid and effective mechanism to ensure consistent application of rules

- Coordinated decision making in some areas in emergency situations.

With respect to the need for harmonization,

- " the lack of a mechanism to resolve the situation whereby an agreement cannot be reached and cooperation is required between national supervisors of cross border groups(within colleges of supervisors);

- The fact that many technical rules are determined at member state level and given considerable differences between member states, ${ }^{26}$

were highlighted as being crucial in propagating the realization of the need for technical standards. Further, a fragmented system of supervision, it is added, "undermines the single market, imposes extra costs for financial institutions, and increases the likelihood of failure of financial institutions with potentially additional costs for tax payers."27

Since macro prudential oversight is not integrated with micro prudential supervision in the European wide framework, and given the fact that supervision will continue to be carried out primarily by

\section{5}

See Europa Press Releases, "European System of Financial Supervisors (ESFS): Why are New European Supervisory Authorities Needed?” <http://europa.eu/rapid/pressReleasesAction.do? reference $=M E M O / 09 / 404>$

26

See ibid 
national supervisory authorities, ${ }^{28}$ effective coordination and timely communication - as well as harmonization are required to assume immensely crucial roles if the objectives of the framework are to be realized.

\section{E. The Need for Improved Coordination between Micro and Macro Prudential Aspects of Financial Supervision}

In drawing attention to particular areas, paragraph 11 of the Preamble to the Regulation ${ }^{29}$ on European Union Macro-prudential Oversight of the Financial System and Establishing a European Systemic Risk Board acknowledges the need for greater efforts in initiatives aimed at improving macro prudential oversight. The areas are as follows: ${ }^{30}$

- The present arrangements of the European Union - which place insufficient emphasis on macro-prudential oversight and inter linkages between developments in the broader macroeconomic environment and the financial system.

- Responsibility for macro prudential analysis being fragmented and conducted by different authorities at corresponding levels

- Lack of mechanism to ensure that macro prudential risks are adequately identified and that warnings and recommendations are issued clearly, followed up and translated into action

- The need for enhanced consistency between macro and micro prudential supervision - to ensure proper functioning of the European Union and global financial systems, as well as the mitigation of threats.

In response to the first identified area, the importance of effective coordination between micro and macro prudential supervision within the financial system as well as the symbiotic relationship between macro and micro prudential supervision is further highlighted by way of reference to the De Larosiere Report: $^{31}$

28

See European Central Bank, Financial Stability Review December 2010 at page 60

29

Regulation (EU) No 1092/2010; L 331/1 15.12.2010, Official Journal of the European Union <http://eur-lex.europa.eu/LexUriServ/LexUriServ.do?uri=OJ:L:2010:331:0001:0011:EN:PDF>

See ibid 
"The De Larosiere Report also states that macro-prudential oversight is not meaningful unless it can somehow impact at micro level whilst micro prudential supervision cannot effectively safeguard financial stability without adequately taking account of macro developments."

In drawing a comparison between macro prudential frameworks which exist at EU level, as well as that which exists in the US and the UK, the following observations can be made: ${ }^{32}$

- Even though the prominent role assumed by the European Central Bank as a "provider of analytical and statistical support to the European Systemic Risk Board" is highlighted (as well as the prominent roles assumed by central banks in the UK and the US), the absence of a "macro prudential oversight which is integrated with micro prudential supervision" in the EU macro prudential framework is a factor which distinguishes it from other frameworks in the analysis.

Given the role of national central banks as guardians of financial stability, the ECB's leading role for macro prudential oversight would also require an incorporation of the roles of national central banks given the expertise and knowledge base of these central banks. Harmonized standards should facilitate the tasks of the European Central Bank - particularly in situations where supervision at the level of a branch in another Member State will no longer be required - for example, as is the case with harmonized liquidity standards. ${ }^{33}$

\section{The ECB's Macro Prudential Expertise}

The ECB's expertise in matters related to macro prudential issues, its potential to make "significant contribution to the effective macro prudential oversight of the Union's financial system" is highlighted under Paragraph 7 of the Council Regulation (EU) No 1096/2010. ${ }^{34}$ Furthermore, the ECB is to "ensure" that the Secretariat of the ESRB, as well as sufficient human and financial resources is

\section{2}

See European Central Bank, Financial Stability Review December 2010 < http://www.ecb.int/pub/pdf/other/financialstabilityreview201012en.pdf> at page 60

33

See paragraph 25, Commission Services Staff Working Document, "Possible Further Changes to the Capital Requirements Directive : Supervisory Responsibility for Branch Liquidity” at page 12 of 99

Of 17 November 2010: Conferring specific tasks upon the European Central Bank concerning the functioning of the European Systemic Risk Board. See particularly page 1, paragraph 7 of the Official Journal < http://www.esrb.europa.eu/shared/pdf/ESRB-ECB-en.pdf?8ac74a965da0ec649984594b1b406ad4> 
provided. ${ }^{35}$ In confirming the ESRB's role in respect of matters relating to financial stability, paragraph 9 also re iterates the ECB's responsibility in engaging national central banks and supervisors to provide their specific expertise. The ECB is also entrusted with functions aimed at providing analytical, statistical, administrative and logistical support to the ESRB.

Involvement of Micro Prudential Supervisors and Member of the Commission in the work of ESRB.

Paragraphs 24 and 25 of the Regulation (EU) No 1092/2010 36 respectively attribute the roles of micro prudential supervisors and a member of the Commission as being vital to ensuring that the assessment of macro prudential risk is based on complete and accurate information about the developments in the financial system, as well as establishing a link with the macro economic and financial surveillance of the Union. The presence of the President of the EFC is also considered important in "reflecting the role of Member States' ministries responsible for finance", as well as that of the Council "in safeguarding financial stability and performing economic and financial oversight".

\section{Functions of the European Systemic Risk Board}

In order to facilitate the attainment of the objective of effective macro prudential oversight of the financial system within the European Union, the establishment of "arrangements that properly acknowledge the interdependence of micro and macro prudential risks" 37 - and having regard to the fact that " the participation of micro prudential supervisors in the work of the European Systemic Risk Board is essential to ensure that the assessment of macro prudential risk is based on complete and accurate information about developments in the financial system," ${ }^{138}$ the European Systemic Risk Board (ESRB) is designated with the following functions $:^{39}$

35

See paragraph 8; ibid

36

Regulation (EU) No 1092/2010 of the European Parliament and of the Council of 24 November 2010 on European Union Macro Prudential Oversight of the Financial System and Establishing a European Systemic Risk Board. See page 4 of 11 <http://eur-lex.europa.eu/LexUriServ/LexUriServ.do? uri=OJ:L:2010:331:0001:0011:EN:PDF>

37

Regulation (EU) No 1092/2010; L 331/1 15.12.2010, Official Journal of the European Union <http://eur-lex.europa.eu/LexUriServ/LexUriServ.do?uri=OJ:L:2010:331:0001:0011:EN:PDF> at page 4 of 11 
- Determining and/or collecting and analyzing all the relevant and necessary information for the purposes of achieving the objectives under paragraph 1, Article 3;

- Identifying and prioritizing systemic risks;

- Issuing warnings where such systemic risks are deemed to be significant and, where appropriate, making these warnings public;

- Issuing recommendations for remedial action in response to the risks identified and, where appropriate, making these recommendations public;

- Issuing a confidential warning addressed to the Council and providing the Council with an assessment of the situation; ${ }^{40}$

- Monitoring the follow up to warnings and recommendations;

- Cooperating closely with all the other parties to the ESFS ${ }^{41}$ where appropriate, providing the European Supervisory Authorities (ESAs) with information on systemic risks required for the performance of their tasks - and in particular, in collaboration with the ESAs, developing a common set of quantitative and qualitative indicators to identify and measure systemic risk;

39

The ESRB is to carry out these tasks for the purposes of paragraph 1 of the same Article (Article 3) which states that "ESRB shall be responsible for the macro prudential oversight of the financial system within the Union in order to contribute to the prevention or mitigation of systemic risks." Further, the ESRB is also to contribute to "the smooth functioning of the Internal Market." See Chapter One, Article 3 which states the mission, objectives, and tasks of the ESRB (paragraphs 1 and 2). Regulation (EU) No 1092/2010; L 331/1 15.12.2010, Official Journal of the European Union <http://eur-lex.europa.eu/LexUriServ/LexUriServ.do? uri=OJ:L:2010:331:0001:0011:EN:PDF > at page 5 of 11

40

„In order to enable the Council to assess the need to adopt a decision addressed to the ESAs determining the existence of an emergency situation"

The ESFS comprise:

No $1093 / 2010$;

(a) the ESRB;

(b) the European Supervisory Authority (European Banking Authority) established by Regulation (EU)

(c) the European Supervisory Authority (European Insurance and Occupational Pensions Authority) established by Regulation (EU) No 1094/2010;

(d) the European Supervisory Authority (European Securities and Markets Authority) established by Regulation (EU) No 1095/2010;

(e) the Joint Committee of the European Supervisory Authorities (Joint Committee) provided for by Article 54 of Regulation (EU) No 1093/2010, of Regulation (EU) No 1094/2010 and of Regulation (EU) No 1095/2010;

(f) the competent or supervisory authorities in the Member States as specified in the Union acts referred to in Article 1(2) of Regulation (EU) No 1093/2010, of Regulation (EU) No 1094/2010 and of Regulation (EU) No 1095/2010." See Chapter One Article One paragraph 3. 
- Participating, where appropriate, in the Joint Committee;

- Coordinating its actions with those of international financial organizations, particularly the IMF and FSB;

- Carrying out other related tasks as specified in Union legislation.

\section{F. Shadow Banking}

Further concerns attributed to the new Basel III framework relate to its "facilitation of the shadow banking system whilst constraining the bank sector." ${ }^{\prime 2}$ The new, more stringent capital and liquidity requirements introduced through Basel III are likely to impact the more highly regulated banking sector since it is likely that there will be greater incentives to transact in less stringent regulated sectors such as the shadow banking system or through less stringent regulated capital instruments.

The "shadow banking system" can generally be described as "credit intermediation involving entities and activities outside the regular banking system." ${ }^{* 3}$ The shadow banking system can also be interpreted as "a system which reallocates the three ${ }^{44}$ functions of banks across a variety of specialist, non bank financial intermediaries, each of which has a distinctive comparative advantage." ${ }^{\$ 4}$

Some examples of shadow banks include finance companies, structured investment vehicles, asset backed commercial paper (ABCP) conduits, limited-purpose finance companies, credit hedge funds, money market mutual funds, securities lenders, and government sponsored enterprises. ${ }^{46}$ Hybrid

\section{2}

See BRIEF, „Deutsche Bank CFO Says Concerned New Basel Rules Allow Shadow Banking System Whilst Constraining Bank Sector“ < http://www.finanznachrichten.de/nachrichten-2011-05/20264700-briefdeutsche-bank-cfo-says-concerned-new-basel-rules-allow-shadow-banking-system-020.htm

43

Financial Stability Board, „Shadow Banking: Scoping the Issues (A Background Note of the Financial Stability Board) http://www.financialstabilityboard.org/publications/r 110412a.pdf at page 3 of 11

44

Such three functions of credit intermediation being referred to as credit, maturity and liquidity transformation. See Pozsar et al, "Shadow Banking” Staff Report No 458, July 2010 < http://www.ny.frb.org/research/staff reports/sr458.pdf> at page 18

45

See ibid at page 19; Shadow banks are also defined as „financial intermediaries that conduct maturity, credit and liquidity transformation without access to central bank liquidity or public sector credit guarantees. "See ibid at page 11.

46

See abstract; ibid. "As well as activities which appear to have a restricted purpose other than regulatory capital arbitrage, shadow banking also includes activities which appear to have significant economic value 
capital instruments, a component of shadow banking, play an important role in the ongoing capital management of credit institutions - such instruments enabling credit institutions to achieve a diversified capital structure as well as providing access to a wide range of financial investors. ${ }^{47}$ However, as it will be demonstrated later on, such instruments also provide opportunities for practices associated with regulatory arbitrage.

Shadow banking can be classified into three distinct subsystems namely: ${ }^{48}$

- Government sponsored shadow banking

- The internal banking shadow sub system

- The external banking shadow sub system

\section{Similarities between Shadow Banking and Traditional Banking ${ }^{49}$}

1) Three actors feature prominently within the traditional banking and shadow banking systems. Whilst savers and borrowers are common to both banking systems, specialist non bank financial intermediaries (or shadow banks) feature within the shadow banking system - in contrast to banks (which feature as the third actor in traditional banking systems).

2) Just as is the case with traditional banking, the shadow banking system conducts credit intermediation.

outside the traditional banking system." See ibid at page 12

\section{7}

See paragraph 3 of the Preamble to the Directive 2009/111/EC of the European Parliament and of the Council of 16 September 2009 (amending Directives 2006/48/EC; 2006/49/EC and 2007/64/EC as regards banks affiliated to central institutions, certain own funds items, large exposures, supervisory arrangements, and crisis management).

48

See Pozsar et al, "Shadow Banking" Staff Report No 458, July 2010 < http://www.ny.frb.org/research/staff reports/sr458.pdf> at page 20 


\section{Shadow Banking distinguished from Traditional Banking}

In distinguishing between the traditional and shadow banking systems, two characteristics will be highlighted - both relating to the similarities highlighted above. Whilst savers place their funds with banks under the traditional banking system, savers under the shadow banking system do not place their funds with banks - but rather with money market mutual funds and similar funds which invest these funds in the liabilities of shadow banks. ${ }^{50}$

Furthermore, unlike the situation which exists with traditional banking - where credit intermediation is performed "under one roof" - that of a bank, credit intermediation under shadow banking is performed "through a chain of non bank financial intermediaries and through a granular set of steps."

\section{Advantages and Disadvantages of Shadow Banking}

An advantage of intermediating credit through non bank channels is the ability of the shadow banking system to provide market participants and corporations with an alternative source of funding and liquidity. ${ }^{51}$

However, shadow banking also provides opportunities whereby channels facilitating regulatory arbitrage (as well as practices undermining the observance of strict bank regulations) are encouraged. Three identified channels of arbitrage include: ${ }^{52}$

i) Cross-border regulatory systems arbitrage

ii) Regulatory, tax and economic capital arbitrage

iii) Ratings arbitrage

50

„Borrowers still get loans, leases and mortgages - not only from depository institutions, but also from entities such as finance companies."; In relation to the second distinguishing feature between traditional banking and shadow banking, the "granular set of steps" through which credit intermediation under shadow banking is carried out include i) Loan origination ii) Loan warehousing iii) ABS (Asset backed securities) issuance iv) ABS warehousing v) ABS CDO (Collateralized debt obligations) issuance vi) ABS "intermediation" and vii) wholesale funding; see ibid.

51

See Financial Stability Board, „Shadow Banking: Scoping the Issues (A Background Note of the Financial Stability Board) http://www. financialstabilityboard.org/publications/r 110412a.pdf at page 3 of 11 
These arbitrage opportunities, it is argued, ${ }^{53}$ emerged from i) The fractured nature of the global financial regulatory framework ii) the dependence of capital adequacy rules (Basel II) on credit ratings; and iii) a collection of one-off uncoordinated decisions by accounting and regulatory bodies regarding the accounting and regulatory capital treatment of certain exposures and lending and asset management activities.

The original 1988 Basel Accord is also widely acknowledged to have contributed to capital arbitrage. In particular, capital arbitrage was is a primary reason why Basel II was introduced. Basel II was introduced as a means of providing for a choice ${ }^{54}$ of three broad approaches to credit risk.

In dedicating the focus on capital arbitrage, reference is made to the potential of the shadow banking system to trigger systemic risks through the provision of credit, maturity and liquidity transformations - a situation which could arise where parts of the shadow banking system are able to function without "internalizing the true costs of its risks - hence gaining a funding advantage relative to banks where regulation aims to achieve such an internalization - which is likely to create opportunities for arbitrage that might undermine bank regulation and lead to a build up of additional leverage and risks in the system." ${ }^{25}$

Whereby maturity transformation involves the transformation of short term liabilities into mediumlong term assets (such as loans), liquidity transformation involves the financing of illiquid assets through liquid liabilities.

53

See ibid

54

The Standardised Approach to Credit Risk was introduced as a means of "aligning regulatory capital requirements more closely with the key elements of banking risk by introducing a wider differentiation of risk weights and a wider recognition of credit risk mitigation techniques, while avoiding excessive complexity." It was intended that the approach would generate capital ratios more in line with the actual economic risks that banks are facing, compared to the original 1988 Basel Capital Accord - which should "improve the incentives for banks to enhance the risk measurement and management capabilities and should also reduce the incentives for regulatory capital arbitrage". See Basel Committee on Banking Supervision, "Consultative Document, The Internal Ratings Based Approach: Supporting Document to the New Basel Capital Accord" January 2001, Bank for International Settlements Publications at page $1<\mathrm{http}: / / \mathrm{www}$.bis.org/publ/bcbsca04.pdf>

"The provision of maturity/liquidity transformation and leverage could make credit intermediation by non bank entities "bank-alike" and raise concerns for authorities to the extent that they create systemic risks. See Financial Stability Board, ,Shadow Banking: Scoping the Issues (A Background Note of the Financial Stability Board) http://www.financialstabilityboard.org/publications/r 110412a.pdf at page 3 (page 5 of 11) 


\section{G. Efforts Aimed at Addressing Regulatory Arbitrage}

The rapid growth of OTC derivative markets whose operations are carried out on a cross border basis - such operations including transactions carried out for the purposes of "hedging, investing, exploiting arbitrage opportunities and position-taking" ${ }^{\text {"6 } 6}$ amongst other activities, not only calls for greater efforts aimed at fostering international cooperation and coordination, but also efforts aimed at deterring regulatory arbitrage practices - hence mitigating the potential for the build up of systemic risks.

The following recommendations have been put forward as means of minimizing regulatory arbitrage with the ultimate objective of mitigating systemic risk: ${ }^{57}$

- The need for authorities to implement mandatory clearing requirements in a manner conducive to the goal of systemic risk reduction - with limited exemptions being granted when possible. Such limited exemptions being granted with the view that the non subjection of a product to mandatory requirements could create potential for regulatory arbitrage. ${ }^{58}$

- IOSCO , in collaboration with other authorities as appropriate, is to coordinate the application of central clearing requirements on a product and participant level - as well as any exemptions from these.

- The prevention of the outsourcing of derivative operations into smaller financial entities would be facilitated by requiring all financial institutions to comply with mandatory clearing requirements - hence reducing possibilities for regulatory arbitrage within the financial sector.

- Where central counterparties compete with each other or operate in multiple jurisdictions, consistent standards of oversight of such central counterparties are not only important as means of preventing such counterparties from attempting to attract clearing volume (through the lowering of margining or other risk management requirements), but also important as a means of preventing regulatory arbitrage.

- Differences in the definitions and regulation of exchanges and electronic trading platforms (which exist across jurisdictions and provide a range of trading fora), whilst being aimed at

\section{6}

9

See Financial Stability Board, „Implementing OTC Derivatives Market Reforms“ October 2010 at page

57

See ibid at pages $26,27,30$ and 40

This being the case since „market participants may design contracts so that they fit the terms of a product that does not require clearing. As a result, authorities will need to actively monitor whether such contract designs are occurring on a material scale." 
addressing different types of participant trading needs, may provide the potential for regulatory arbitrage practices.

Where a jurisdiction or authority decides to exempt non financial entities from applying mandatory clearing requirements, the importance of such a jurisdiction or authority ensuring that such exemptions, "either on a collective or individual firm basis, do not present systemic risk or undermine the benefits of CCP clearing for the market", is also re-iterated. This being the case particularly, since as rightly argued, the application of mandatory clearing requirements to the largest financial firms may prove futile since "positions of small firms in the OTC derivatives markets may be significant. While the default of a large financial firm is likely to have a systemic impact, experience suggests that the degree of interconnectedness is also an important determinant of systemic relevance. Thus authorities will need to actively monitor OTC derivatives market activities to determine whether the activity of exempt entities is of a scale that could present systemic risk." ${ }^{59}$

\section{H. Conclusion}

A harmonized set of standards, particularly at macro prudential level, is essential to the facilitation of coordination, as well as the aim of achieving the objectives of mitigating systemic risks, regulatory arbitrage practices and facilitating the vital roles of supervisors (and particularly those of crucial players such as central banks).

However, harmonized standards should apply as benchmarks which should not be significantly deviated from where the need for such deviation arises and is justified - given the individual and exceptional circumstances of those seeking such a deviation.

Coordination which is aimed at achieving prompt and timely communication is a vital goal which the refined macro prudential frameworks should endeavour to attain. In order to achieve such an aim, central banks' expertise and the vital roles they assume will be required in facilitating the objectives of mitigating systemic risks, effective coordination and communication, as well as the mitigation of regulatory arbitrage. Further, the mitigation of systemic risks through the redress of shadow banking channels which could facilitate regulatory arbitrage practices, as well as the efficient functioning of new macro prudential frameworks will help ensure that new Basel III standards' objectives to facilitate greater financial stability on a macro prudential basis are not undermined by possibilities and gaps which could foster capital arbitrage and the building up of systemic risks.

59

See ibid at pages 27 and 28. "Furthermore, if a jurisdiction chooses to exempt such participants from mandatory clearing requirements, international coordination, as well as the ongoing need to monitor whether the grounds on which a participant has been exempted continue to apply, will be critical to reducing the scope for regulatory arbitrage." See ibid at page 28 


\section{REFERENCES}

Basel Committee on Banking Supervision, "Consultative Document, The Internal Ratings Based Approach: Supporting Document to the New Basel Capital Accord" January 2001, Bank for International Settlements Publications http://www.bis.org/publbcbsca04.pdf

BRIEF, „Deutsche Bank CFO Says Concerned New Basel Rules Allow Shadow Banking System Whilst Constraining Bank Sector" http://www.finanznachrichten.de/nachrichten-2011-05/20264700brief-deutsche-bank-cfo-says-concerned-new-basel-rules-allow-shadow-banking-system-020.htm

Commission Communication, "From Financial Crisis to Recovery: A European Framework for Action” COM (2008) 706 final 29 October 2008 http://eur-lex.europa.eu/LexUriServ/LexUriServ.do? uri=COM:2008:0706:FIN:EN:PDF

DIRECTIVE 2009/111/EC OF THE EUROPEAN PARLIAMENT AND OF THE COUNCIL of 16 September 2009 amending Directives 2006/48/EC, 2006/49/EC and 2007/64/EC as regards banks affiliated to central institutions, certain own funds items, large exposures, supervisory arrangements, and crisis management

DIRECTIVE 2006/48/EC OF THE EUROPEAN PARLIAMENT AND OF THE COUNCIL of 14 June 2006 relating to the taking up and pursuit of the business of credit institutions

DIRECTIVE 2006/49/EC OF THE EUROPEAN PARLIAMENT AND OF THE COUNCIL of 14 June 2006 on the capital adequacy of investment firms and credit institutions

European Central Bank, Financial Stability Review December 2010

$<$ http://www.ecb.int/pub/pdf/other/financialstabilityreview201012en.pdf

Europa Press Releases, “European System of Financial Supervisors (ESFS): Why are New European Supervisory Authorities Needed?" http://europa.eu/rapid/press ReleasesAction.do? reference $=M E M O / 09 / 404$

Financial Stability Board, “Implementing OTC Derivatives Market Reforms” Oct 2010 http://www.financialstabilityboard.org/publications/r 101025.pdf

Financial Stability Board, „Shadow Banking: Scoping the Issues (A Background Note of the Financial Stability Board) http://www.financialstabilityboard.org/publications/r 110412a.pdf

Pozsar et al, "Shadow Banking” Staff Report No 458, July $2010<$ http://www.ny.frb.org/research/staff reports/sr458.pdf>

Regulation (EU) No 1092/2010 of the European Parliament and of the Council of 24 November 2010 on European Union Macro Prudential Oversight of the Financial System and Establishing a European Systemic Risk Board. http://eur-lex.europa.eu/LexUriServ/LexUriServ.do? uri=OJ:L:2010:331:0001:0011:EN:PDF

Regulation (EU) No 1096/2010 of 17 November 2010: Conferring Specific Tasks Upon the European Central Bank Concerning the Functioning of the European Systemic Risk Board. 


\section{ANNEX}

Source: Federal Reserve Bank New York, Shadow Banking, Pozsar et al $<$ http://www.ny.frb.org/research/staff_reports/sr458.pdf>

\begin{tabular}{|c|c|c|c|}
\hline & Function & Shadow Banks & Shadow Banks' Funding* \\
\hline Step (1) & Lom Origination & - & - \\
\hline Step (2) & Lown Wraehousing & Multi-seller conduits & $A B C P$ \\
\hline Step (3) & AB5 Issumee & 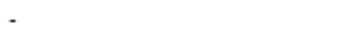 & - \\
\hline Step (4) & ABS Wurehousing & Hyorid and TRS/repo conduits & $A B C P$ \\
\hline Step (5) & ABS CDO Issumes & - & - \\
\hline Step (6) & AB5 Intermediation & Securities axbitrage conduits and SIV: & $A B C P, M T N$ and opital notes \\
\hline Step (7) & Wholes ale Funding & - & - \\
\hline
\end{tabular}

Source: Shadow Bunking (Pozsas, Adain, Ashasft, Boesky (2010)] 

Source: European Central Bank, Financial Stability Review, December 2010 at page 61

<http://www.ecb.int/pub/pdf/other/financialstabilityreview201012en.pdf >

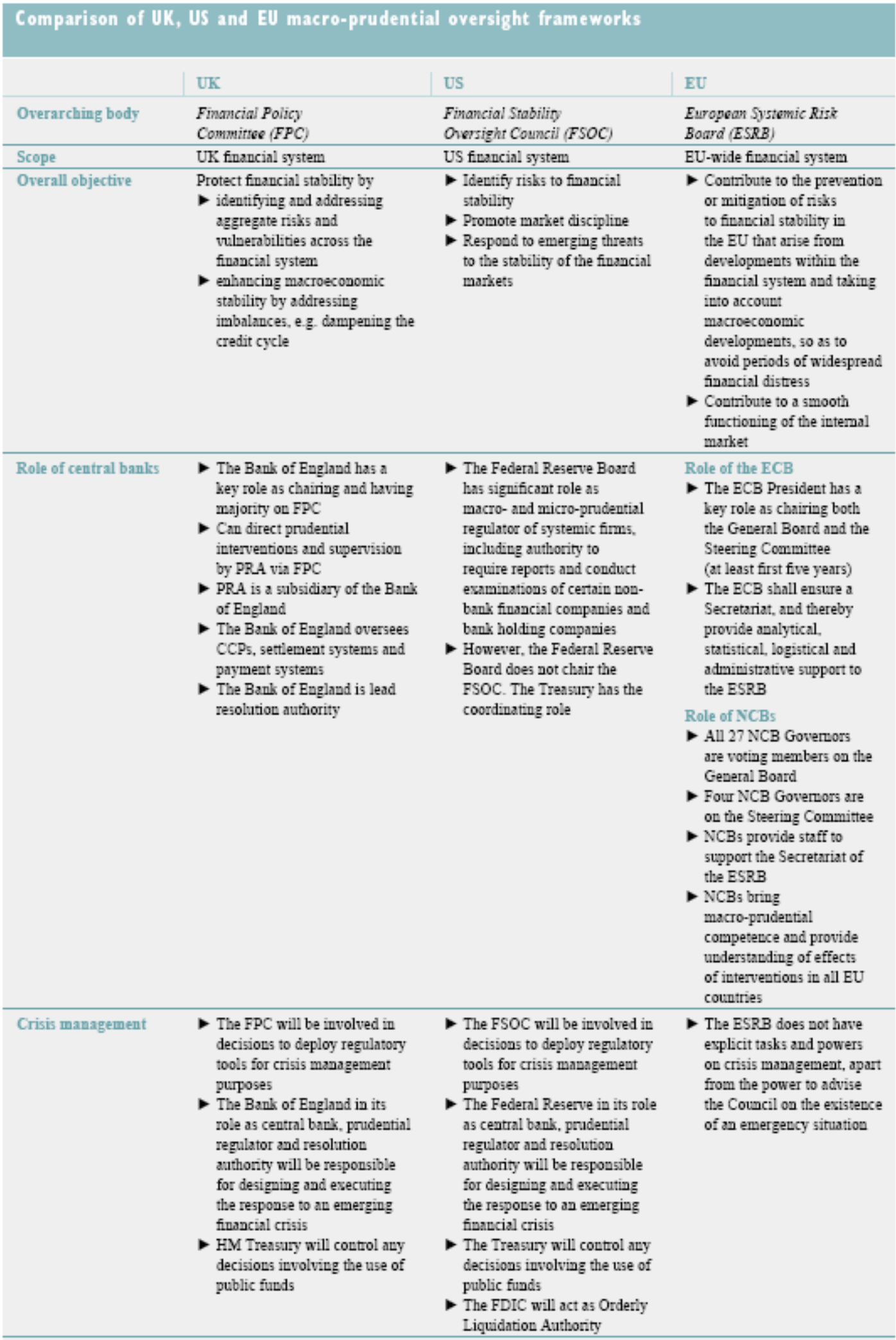


